\title{
FIRST RECORD OF DITTRICHIA GRAVEOLENS (ASTERACEAE, INULEAE) IN CHILE
}

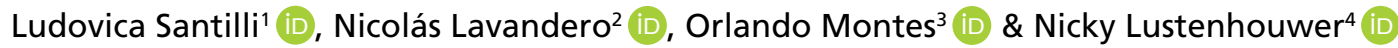

\begin{abstract}
${ }^{1}$ Museo Nacional de Historia Natural, Area Botánica, Interior Parque Quinta Normal S/N, Casilla 787, Santiago, Chile; santilli.ludovica@gmail.com (author for correspondence).

${ }^{2}$ Departamento de Ecología, Facultad de Ciencias Biológicas, Pontificia Universidad Católica de Chile, Santiago, Chile.

${ }^{3}$ Independent researcher, Chile.

${ }^{4}$ Department of Ecology and Evolutionary Biology, University of California, Santa Cruz, California, USA.
\end{abstract}

\begin{abstract}
Santilli, L.; N. Lavandero, O. Montes \& N. Lustenhouwer. 2021. First record of Dittrichia graveolens (Asteraceae, Inuleae) in Chile. Darwiniana, nueva serie 9(1): 31-38.

Dittrichia graveolens is reported for the first time for the flora of Chile and for the Southern Cone. A brief description as well as illustrative pictures of the species and the habitat are provided. Furthermore, we present a map of the site where the population was found and a short key to the species of Dittrichia present in Chile. Insights about its potential invasiveness are discussed.
\end{abstract}

Keywords. Exotic flora; invasive species; South America; Southern Cone; weed.

Resumen. Santilli, L.; N. Lavandero, O. Montes \& N. Lustenhouwer. 2021. Primer registro de Dittrichia graveolens (Asteraceae, Inuleae) en Chile. Darwiniana, nueva serie 9(1): 31-38.

Dittrichia graveolens se reporta por primera vez para la flora de Chile y para el Cono Sur. Se provee una breve descripción e imágenes ilustrativas de la especie y su hábitat. Adicionalmente, se presenta un mapa del sitio donde se encontró la población y una clave de las especies de Dittrichia presentes en Chile. Se discute su potencial invasor.

Palabras claves. Cono Sur; especies invasoras; flora exótica; maleza; Sudamérica.

\section{INTRODUCTION}

The genus Dittrichia Greuter belongs to the Asteraceae and includes five species native to the Mediterranean basin (Brullo \& de Marco, 2000), two of which are currently widespread in other regions (Parsons \& Cuthbertson, 2001; Brownsey et al., 2013a; Lustenhouwer et al., 2018). They are annual or perennial herbs, with glandular and hairy indumentum, simple leaves, female ligulate flowers and hermaphrodite tubular flowers. Dittrichia differs from the closely related genus Inula L. by the presence of cylindrical achenes abruptly contracted below the pappus, and pappus-hairs connate near the base, versus angled achenes, not abruptly contracted below the pappus, and simple and free pappus-hairs (Brullo \& de Marco, 2000). Regarding their ecology, species of Dittrichia are generally associated with synanthropic places, rocky coastal habitat, cultivated land and gravel riverbeds (Brullo \& de Marco, 2000). Due to their adaptation to disturbed open habitats as well as their efficient seed production and dispersal (Parolin et al., 2014), species of Dittrichia are considered invasive in California (Brownsey et al., 2013a; DiTomaso \& Brownsey, 2013), Australia (Parsons $\&$ Cuthbertson, 2001) and recently colonized areas of Europe (DAISIE, 2020). 
Recording new introductions of exotic species is essential given the important threat biological invasions represent for local biodiversity (Ehrenfeld, 2010; Pyšek et al., 2012). In Chile, between 106 and 116 introduced species of Asteraceae have been reported at the country level (Fuentes et al., 2013; Ray et al., 2014; Rodríguez et al., 2018). No species of Dittrichia had been recorded for South America until Novoa (2017) reported the presence of the first naturalised species of the genus, Dittrichia viscosa (L.) Greuter, in an urban environment in Curauma, Chile (Valparaíso Region).

The aim of the present work is to report the presence of Dittrichia graveolens (English: stinkwort; Spanish: olivardilla) for the exotic flora of Chile.

\section{MATERIALS AND METHODS}

On June 2020, a user of iNaturalist, an online social network of people sharing biodiversity data (https://www.inaturalist.org/) brought an unknown plant species to the attention of the community that was photographed on the riverside of Río Mapocho, within the city of Santiago, Chile (https://www. inaturalist.org/observations/50942000). The species was identified by the community as Dittrichia graveolens (L.) Greuter. To confirm the identity of the species and to evaluate its population size, a field survey was conducted in the whereabouts of the previous finding in December 2020, over an area encompassing approximately $10,000 \mathrm{~m}^{2}$ (Fig. 1). A second locality for $D$. graveolens was recorded on the nearby hill of Cerro San Cristobal (Fig. 1).

A morphological analysis was performed in order to confirm the identity of the specimens, which were compared against high resolution images of the type material of D. graveolens and the taxonomic revision of the genus Dittrichia (Brullo \& de Marco, 2000). In addition, we consulted the botanical literature for possible records of the species for the country (e.g., Marticorena \& Quezada, 1985; Matthei, 1995; Rodríguez et al., 2018; Zuloaga et al., 2019; Fuentes et al., 2020). Collected specimens were deposited at SGO (acronyms following Thiers, 2020).

We give a brief description of the species and of the localities where it is found growing and provide a key for the species of Dittrichia present in Chile. Terminology describing plant morphology follows Beentje (2016).

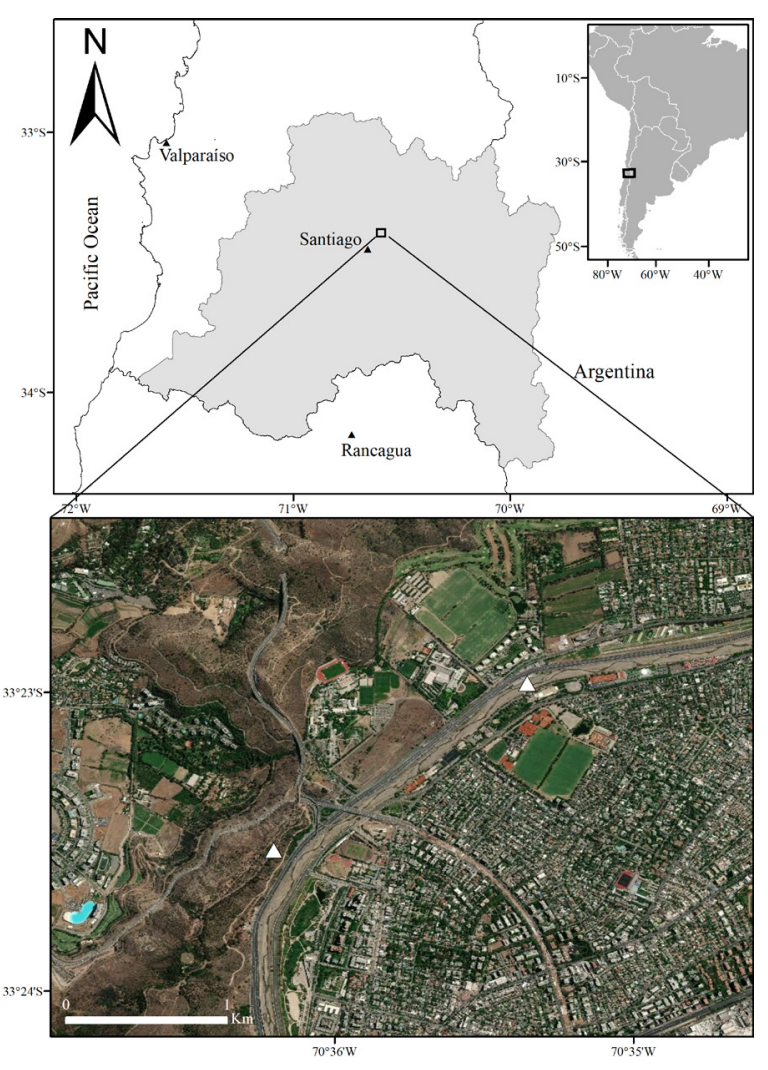

Fig. 1. Localities of Dittrichia graveolens found in Chile (white triangles). Left, Cerro San Cristóbal, Santiago and right, Río Mapocho, Santiago. Satellite Image source: Esri, DigitalGlobe, Geoeye, Earthstar Geographics, CNES/Airbus DS, USDA, USGS, AeroGRID, IGN, GIS User Community. Color version at http://www.ojs.darwin. edu.ar/index.php/darwiniana/article/view/938/1205

\section{RESULTS AND DISCUSSION}

Dittrichia graveolens (L.) Greuter, Exsicc. Genav. Conserv. Bot. Distrib. Fasc. 4: 71. 1973. $\equiv$ Erigeron graveolens L., Cent. P1. I.: 28. 1755. TYPE: "Habitat Monspelii" (lectotype, LINN994.4, digital image! Available in: http://linneanonline.org/10083; designated by Grierson in Davis (ed.), Fl. Turkey 5: 72. 1975). Fig. 2A-E.

Plant annual, herbaceous erect, up to $60 \mathrm{~cm}$ high, covered in glandular hairs, with a strong camphor scent. Leaves up to $60 \times 8 \mathrm{~mm}$, linear-lanceolate, mostly conduplicate, sessile to subamplexicaul, margins subentire. Capitulescence terminal and 


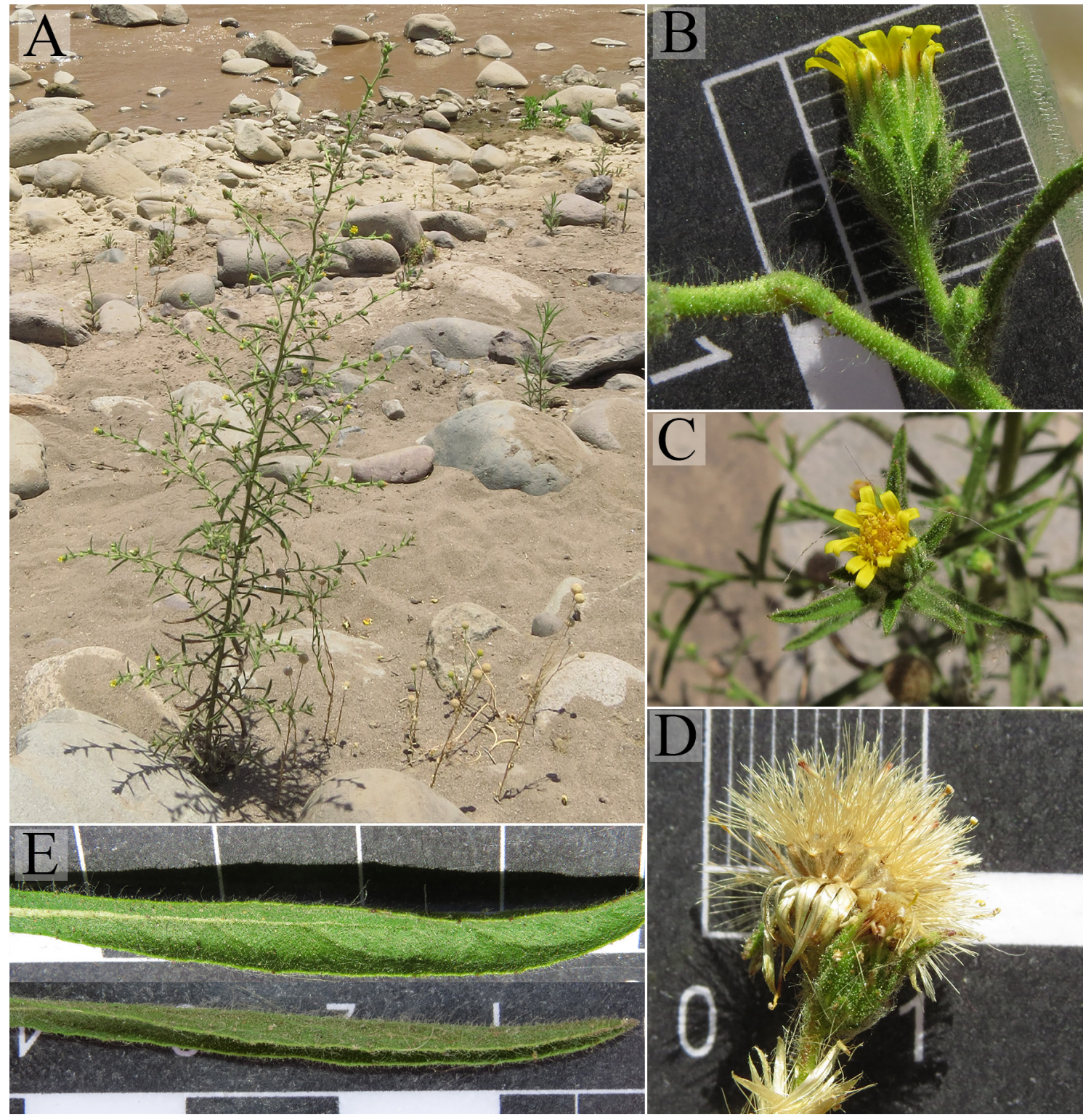

Fig. 2. Dittrichia graveolens. A, habit. B, side view of a capitulum. C, top view of a capitulum. D, close-up of achenes. E, adaxial (above) and abaxial (below) side of a leaf. Color version at http://www.ojs.darwin.edu.ar/ index.php/darwiniana/article/view/938/1205

axillary, capitulum involucre up to $7 \mathrm{~mm}, 6 \mathrm{~mm}$ diam.; calyculus covered in glandular hairs, bracts reflexed, each bract up to $6 \times 1.5 \mathrm{~mm}$; phyllaries with hyaline margins, glandular, up to $7 \times 1 \mathrm{~mm}$. Female flowers yellow, ligulate, slightly protruding the involucre. Hermaphrodite flowers yellow, tubular, erect. Achenes up to $2 \mathrm{~mm}$, covered in hairs; pappus up to $4 \mathrm{~mm}$.
Diagnosis. D. graveolens differs from $D$. viscosa in having an annual (vs. perennial) life cycle, subentire (vs. serrate) leave margins, and reflexed (vs. appressed) bracts of calyculus.

References. For a detailed description see Brullo $\&$ de Marco (2000). 
Iconography. See Sibthorp \& Lindley (1837: 866); Brullo \& de Marco (2000: 349, Fig. 1E; 350, Fig. 2E; 351, Fig. 3E; 352, Fig. 4E; 353, Fig. 5E-6E); Preston (2007: 472).

Distribution and habitat. Dittrichia graveolens is native to the Mediterranean basin, extending east to north-west India (Brullo \& de Marco, 2000). Coinciding with recent climate change in central Europe, the species is currently undergoing a dramatic northward expansion of its native range which now includes the UK (BSBI, 2020), the Netherlands (Stouthamer, 2007), and Poland (Kocián, 2015). This range expansion may in part have been promoted by the rapid evolution of earlier flowering time in northern populations over the past few decades (Lustenhouwer et al., 2018). Outside its native range, $D$. graveolens has a long history of colonizing regions with a Mediterranean climate on other continents, including Australia (since the 1860s; Parsons \& Cuthbertson, 2001), South-Africa, California (first recorded in 1984; Preston, 1997), and now Chile. According to Brullo \& de Marco (2000), it is considered a nitrophilous species, adapted to anthropic habitats, and occurs mainly on arid soils, where it grows during the summer and autumn period. As Dittrichia graveolens is not listed in the catalogue of the vascular flora of Chile (Marticorena \& Quezada, 1985; Matthei, 1995; Rodríguez et al., 2018; Fuentes et al., 2020) or in the Flora of the Southern Cone (Zuloaga et al., 2008; Zuloaga et al., 2019), this is the first record for the flora of the Southern Cone.

In Chile, we observed Dittrichia graveolens growing on the riverside of Río Mapocho and in Cerro San Cristobal, within the city of Santiago Metropolitan Region (Fig. 1). The former area is characterised by a natural riverbank of sand and rocks with vegetation composed of an assemblage of native and exotic shrubs and herbs such as Baccharis salicifolia (Ruiz \& Pav.) Pers., Centaurea melitensis L., Dysphania ambrosioides (L.) Mosyakin \& Clemants, Eschscholzia californica Cham., Helenium aromaticum (Hook.) L.H. Bailey, Hirschfeldia incana (L.) Lagr.-Foss., Nicotiana acuminata (Graham) Hook., Oenothera stricta Ledeb. ex Link, Pennisetum sp., Ricinus communis L., Tessaria absinthioides (Hook. \& Arn.) DC.,
Verbascum thapsus L., and Verbascum virgatum Stokes (Fig. 3A). In Cerro San Cristobal, D. graveolens grows on rocky soil on the side of the road running across the hill, with Ailanthus altissima (Mill.) Swingle, Acacia dealbata Link, Eucalyptus globulus Labill.

Observations. At least 1000 individuals at various stages of development were found growing in Rio Mapocho, where dry plants from the previous season were also observed (Fig. 3B). Seven additional individuals were observed in Cerro San Cristobal (Fig. 3C).

Uses. Dittrichia graveolens has been widely used in traditional and modern medicine for its antifungal, antibacterial, anti-inflammatory, insecticide and sedative properties (Maxia et al., 2008; Aghel et al., 2011; Mazandarani et al., 2014; Miladinović et al., 2016). It is also known to be poisonous to livestock (Philbey \& Morton, 2000) and causes contact allergic dermatitis in humans (Thong et al., 2008).

\section{Specimens examined}

CHILE. Región Metropolitana. Santiago, Río Mapocho, entre Copec y Casa piedra, 33.382813 S, 70.589241 W, 670 m s.m., 15-XII-2020, Santilli \& Lavandero 201215 (SGO); Santiago, Cerro San Cristobal, camino Federico Albert, entre mirador de la Pirámide y mirador El Sauce, 33.392135 S, 70.603394 W, 700 m s.m., 05-II-2021, Santilli \& Lavandero 210205 (SGO).

\section{Potential invasiveness}

Field observations by the authors suggest that the individuals of $D$. graveolens found in 2020 likely established from seeds produced by individuals from the previous year that can still be observed on site bearing the dried capitula. This suggests that Dittrichia graveolens has surmounted abiotic and biotic barriers to survival and various barriers to natural reproduction, and for this reason can be considered naturalised according to the definition proposed by Richardson et al. (2000). However, following Pyšek et al. (2004), alien species are to be considered naturalised only once they sustain self-replacing populations for at least 10 years without or in spite of human intervention. 


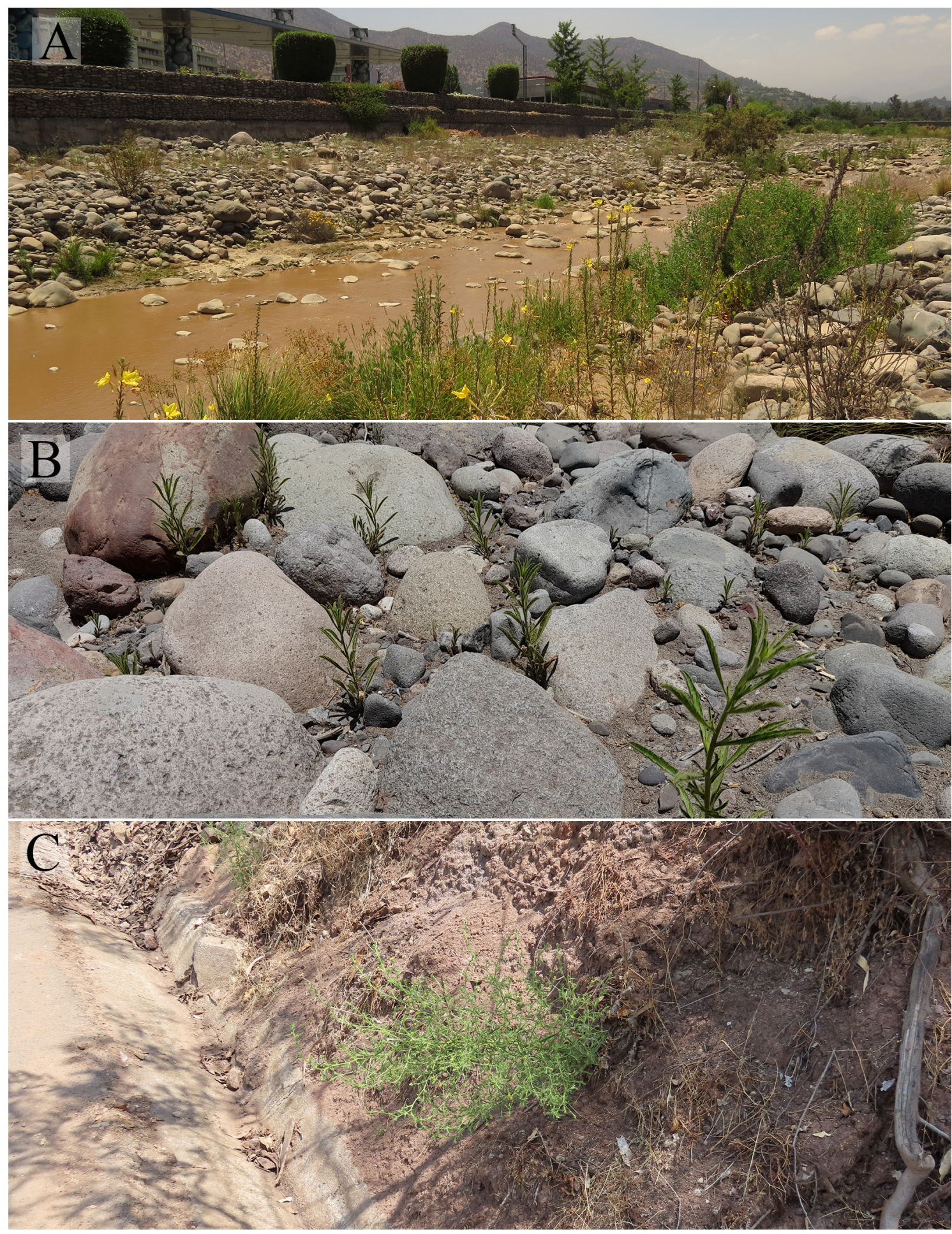

Fig. 3. Dittrichia graveolens. A, habitat showing a sandy-rocky substrate on the riverbank of Río Mapocho. B, detail of the natural regeneration in Rio Mapocho. C, habitat showing a roadside with a rocky soil in Cerro San Cristobal. Color version at http://www.ojs.darwin.edu.ar/index.php/darwiniana/article/view/938/1205 
The habitats where $D$. graveolens was observed, a gravel riparian environment and a roadside with low total vegetative cover (Fig. 3), match the optimal conditions reported in the literature for the plant to thrive. Dittrichia graveolens is in fact reported to establish well in high light conditions in disturbed areas (Brownsey et al., 2013a). While water cannot be excluded as a dispersal vector, it is well known that seeds of $D$. graveolens are largely dispersed by wind (Brownsey et al., 2013a). Given the large number of viable seeds that $D$. graveolens produces and the high availability of light in the adjacent area, we expect the population to keep growing with the possibility to expand its current distribution at least up and down stream in Río Mapocho and along the road in Cerro San Cristóbal. Not to be excluded is also the risk of invasion to other environments, as D. graveolens has been documented to invade overgrazed rangelands (Brownsey et al., 2013b).

Beside the negative effects that this introduction might have on local biodiversity, the species is also known to taint animal products, be poisonous to livestock (Meadly, 1965; Philbey \& Morton, 2000) and cause contact allergic dermatitis in humans (Thong et al., 2008). Brownsey et al. (2013b) showed that because of the absence of primary dormancy, the majority of seeds will germinate under favorable conditions after dispersal, thus an efficient strategy to eliminate the population would be the prevention of seed production for one or two years. This could be achieved mechanically by extirpation of the plants before they start flowering, which appears to be in response to photoperiod (Brownsey et al., 2013a; Lustenhouwer et al., 2018) and thus predictable. It is also important to investigate the point of introduction, as no local extirpation will be successful if an external source persists. The very rapid ongoing range expansion of Dittrichia graveolens in California and Europe illustrates that early detection and management efforts will be key to constrain the distribution of the species in Chile. Roadways are important corridors facilitating the spread of D. graveolens (e.g., Stouthamer, 2007; DiTomaso \& Brownsey, 2013) and should be monitored near existing populations.

\section{Final considerations}

It is worth noting that this discovery was made possible due to the connection facilitated by a citizen science platform for sharing photographed digital vouchers (https://www. inaturalist.org/). One of the benefits of citizen science is that it encourages people to explore the environment and actively participate in collecting data for science, and by doing so democratising access to data and data production. Simultaneously, researchers can greatly benefit from the increasing availability of biological data that are being published and available for use.

\section{Key to Dittrichia species occurring in Chile}

1. Annual plant, leaves margin subentire, bracts of calyculus reflexed, phyllaries with hyaline margins, female flowers slightly protruding the involucre ..... D. graveolens

1. Perennial plant, leaves margin serrate, bracts of calyculus appressed, phyllaries without hyaline margins, female flowers largely protruding the involucre D. viscosa

\section{ACKNOWLEDGEMENTS}

We thank the staff from SGO for receiving the specimens and two anonymous reviewers for their useful suggestions on the manuscript.

\section{BIBLIOGRAPHY}

Aghel, N.; A. Z. Mahmoudabadi \& L. Darvishi. 2011. Volatile constituents and anti-candida activity of the aerial parts essential oil of Dittrichia graveolens (L.) Greuter grown in Iran. African Journal of Pharmacy and Pharmacology 5(6): 772-775. DOI: https://doi. org/10.5897/AJPP10.145

Beentje, H. J. 2016. The Kew plant glossary: an illustrated dictionary of plant terms. Royal Botanic Gardens Kew, Richmond: Kew Publishing.

BSBI (Botanical Society of Britain and Ireland). 2020.

Distribution Database, https://database.bsbi.org/, accessed June 2020. 
Brownsey, R. N.; G. B. Kyser \& J. M. DiTomaso. 2013a. Growth and phenology of Dittrichia graveolens, a rapidly spreading invasive plant in California. Biological Invasions 16(1): 43-52. DOI: https://doi. org/10.1007/s10530-013-0501-4

Brownsey, R. N.; G. B. Kyser \& J. M. DiTomaso. 2013b. Seed and Germination Biology of Dittrichia graveolens (Stinkwort). Invasive Plant Science and Management 6(3): 371-380. DOI: https://doi.org/10.1614/ IPSM-D-12-00072.1

Brullo, S. \& G. de Marco. 2000. Taxonomical revision of the genus Dittrichia (Asteraceae). Portugaliae Acta Biologica 19(1): 341-354.

DAISIE. 2020. Inventory of alien invasive species in Europe. Version 1.7. Research Institute for Nature and Forest (INBO). Checklist dataset https://doi.org/10.15468/ ybwd3x accessed via GBIF.org on February 2021.

DiTomaso, J. M. \& R. N. Brownsey. 2013. Invasive stinkwort (Dittrichia graveolens) is quickly spreading in California. California Weed Science Society Research Update and News 9: 1-2.

Ehrenfeld, J. G. 2010. Ecosystem Consequences of Biological Invasions. Annual Review of Ecology, Evolution, and Systematics 41(1): 59-80. DOI: https:// doi.org/10.1146/annurev-ecolsys-102209-144650

Fuentes, N.; A. Pauchard, P. Sánchez, J. Esquivel \& A. Marticorena. 2013. A new comprehensive database of alien plant species in Chile based on herbarium records. Biological Invasions 15(4): 847-858. DOI: https://doi. org/10.1007/s10530-012-0334-6

Fuentes, N.; A. Marticorena, A. Saldaña, V. Jerez, J. C. Ortiz, P. Victoriano, R. A. Moreno, J. Larraín, C. Villaseñor-Parada, G. Palfner \& P. Sánchez. 2020. Multi-taxa inventory of naturalized species in Chile. NeoBiota 60: 25-41. DOI: https://doi.org/10.3897/ neobiota.60.55366

Kocián, P. 2015. Dittrichia graveolens (L.) Greuter - a new alien species in Poland. Acta Musei Silesiae, Scientiae Naturales 64(3): 193-197. DOI: https://doi.org/10.1515/ cszma-2015-0027

Lustenhouwer, N.; R. A. Wilschut, J. L. Williams, W. H. van der Putten \& J. M. Levine. 2018. Rapid evolution of phenology during range expansion with recent climate change. Global Change Biology 24(2): 534-544. DOI: https://doi.org/10.1111/gcb.13947

Marticorena, C. \& M. Quezada. 1985. Catálogo de la flora vascular de Chile. Gayana Botánica 42(1-2): 1-157.

Matthei, J. 1995. Manual de las malezas que crecen en Chile. Santiago, Chile: Alfabeta impresores.
Maxia, A.; M. C. Lancioni, A. N. Balia, R. Alborghetti, A. Pieroni \& M. C. Loi. 2008. Medical ethnobotany of the Tabarkins, a Northern Italian (Ligurian) minority in southwestern Sardinia. Genetic Resources and Crop Evolution 55: 911-924. https://doi.org/10.1007/s10722-007-9296-4

Mazandarani, M.; M. Ghafourian \& A. Khormali. 2014. Ethnopharmacology, antibacterial and antioxidant activity of Dittrichia graveolens (L.) W. Greuter. Crescent Journal of Medical and Biological Sciences, 1(4):125-129.

Meadly, G. R. W. 1965. Stinkwort (Inula graveolens Desf.). Journal of the Department of Agriculture, Western Australia Series 4, Vol. 6, No. 7, Article 9.

Miladinović, D. L.; B. S. Ilić, B. D. Kocić, M. S. Marković, L. C. Miladinović. 2016. In Vitro Trials of Dittrichia graveolens Essential Oil Combined with Antibiotics. Natural Product Communications 11(6): 865-8. DOI: https://doi.org/10.1177/1934578X1601100642

Novoa, P. 2017. Dittrichia viscosa (L.) Greuter (Asteraceae): Nuevo registro para la flora introducida de Chile. Gayana Botánica 74(2): 293-295. DOI: https://doi.org/10.4067/ S0717-66432017000200293

Parolin, P.; M. Ion Scotta \& C. Bresch. 2014. Biology of Dittrichia viscosa, a Mediterranean ruderal plant: a review. Phyton 83: 251-262. DOI: https://doi.org/10.32604/ phyton.2014.83.251

Parsons, W. T. \& E. G. Cuthbertson. 2001. Noxious weeds of Australia. Collingwood: CSIRO publishing. pp 281-283.

Philbey, A. W. \& A. G. Morton. 2000. Pyogranulomatous enteritis in sheep due to penetrating seed heads of Dittrichia graveolens. Australian Veterinary Journal 28: 858-60. DOI: https://doi.org/10.1111/j.1751-0813.2000. tb10511.X

Preston, R. E. 1997. Dittrichia graveolens (Asteraceae), new to the California weed flora. Madroño 44(2): 200-203.

Preston, R. E. 2007. Dittrichia. In Flora of North America, North of Mexico. Vol. 19, Magnoliophyta: Asteridae, part 6: Asteraceae. USA: Oxford University Press. pp 472.

Pyšek, P.; D. M. Richardson, M. Rejmánek, G. L. Webster, M. Williamson \& J. Kirschner. 2004. Alien plants in checklists and floras: towards better communication between taxonomists and ecologists. Taxon 53(1): 131-143. DOI: https://doi.org/10.2307/4135498

Pyšek, P.; V. Jarošík, P. E. Hulme, J. Pergl, M. Hejda, U. Schaffner \& M. Vilà. 2012. A global assessment of invasive plant impacts on resident species, communities and ecosystems: the interaction of impact measures, invading species' traits and environment. Global Change Biology 18(5): 1725-1737. DOI: https://doi.org/10.1111/ j.1365-2486.2011.02636.x 
Ray, C.; V. Escobedo-Echeverría, S. Castro \& F. M. Jaksic. 2014. Catálogo de la flora y fauna invasora en Chile continental e insular oceánico. In Jaksic, F. \& S. Castro. Invasiones Biológicas en Chile, causas globales e impactos locales. Santiago: Ediciones Universidad Católica de Chile.

Richardson, D. M.; P. Pyšek, M. Rejmánek, M. G. Barbour, F. D. Panetta \& C. J. West. 2000. Naturalization and invasion of alien plants: concepts and definitions. Diversity and distributions 6(2): 93-107. DOI: https:// doi.org/10.1046/j.1472-4642.2000.00083.x

Rodríguez, R.; C. Marticorena, D. Alarcón, C. Baeza, L. Cavieres, V. L. Finot, N. Fuentes, A. Kiessling, M. Mihoc, A. Pauchard \& E. Ruiz. 2018. Catálogo de las plantas vasculares de Chile. Gayana Botánica 75(1): 1-430. DOI: https://doi.org/10.4067/S071766432018000100001

Sibthorp, J. \& J. Lindley. 1837. Flora Graeca, sive, Plantarum rariorum historia, quas in provinciis aut insulis Graeciae Vol. 9 pp. 866.
Stouthamer, W. 2007. Kamferalant verovert de snelwegen. Floron Nieuws 7: 1.

Thiers, B. 2020. [Continuosly updated] Index Herbariorum: A global directory of public herbaria and associated staff. New York Botanical Garden's Virtual Herbarium. Available from http://sweetgum.nybg.org/science/ih/. Last accessed: December 2020.

Thong, H. Y.; M. Yokota \& D. Kardassakis. 2008. Allergic contact dermatitis from Dittrichia graveolens (L.) Greuter (stinkwort). Contact Dermatitis 58: 51-3. DOI: https://doi.org/10.1111/j.1600-0536.2007.01154.x

Zuloaga, F. O.; O. Morrone \& M. Belgrano. 2008. Catálogo de las plantas vasculares del Cono Sur (Argentina, sur de Brasil, Chile, Paraguay y Uruguay). St. Louis, USA: Monographs in Systematic Botany from the Missouri Botanical Garden Press.

Zuloaga, F. O.; M. Belgrano \& C. A. Zanotti. 2019. Actualización del Catálogo de las Plantas Vasculares del Cono Sur. Darwiniana nueva serie 7(2): 208-278. DOI: https://doi.org/10.14522/darwiniana.2019.72.861 